\title{
Jaromír Krško
}

Univerzita Mateja Bela, Banská Bystrica

\section{Komunikačný register a proprium ${ }^{1}$}

\section{1. Úvod}

Pri koncipovaní tohto príspevku sme vyšli zo základnej premisy, že jazyk je sociálny jav. Bez jazyka by nebola spoločnost'v takej podobe, ako ju poznáme a bez spoločnosti by nebol jazyk.

Súčasná onomastika, na rozdiel od tradičnej, ktorá sa sústred'ovala predovšetkým na etymológiu propria, sústred’uje svoju pozornost' na komplexné pochopenie vzniku a fungovania propria $\mathrm{v}$ rôznych komunikačných prostrediach a situáciách. Na takéto široké ponímanie problematiky proprií využíva onomastika poznatky iných vedných disciplín. Nášmu chápaniu propria ako súčasti jazyka, ktorý je sociálnym fenoménom, má preto vel'mi blízko sociolingvistika, sociológia a psychológia.

Sociálnemu chápaniu vlastných mien venujeme pozornost' takmer 15 rokov. Prvotné štúdie sa týkali predovšetkým toponým, postupne sa však naše chápanie rozšírilo na vlastné meno vo všeobecnosti. Prvotné termíny ako mikrosociálne toponymum [pozri Krško 1998a, b], sociálne toponymum [Krško 2003b], sociálne antroponymum [Krško 2003c] napokon vyústili do chápania proprií v rámci komunikačného registra jednotlivca a sociálnej skupiny, ktorej členom je tento jednotlivec.

\section{Komunikačný register $v$ apelatívnej rovine}

Sociolingvistické výskumy zameriavajú pozornost' na faktory, ktoré pôsobia na fungovanie a používanie jazyka ako dorozumievacieho prostriedku. Jedným z takýchto dôležitých faktorov je spoločnost' a jej diferenciácia na rôznorodé sociálne a profesijné spoločenstvá. Sociolingvistický výskum na Prešovskej

${ }^{1}$ Tento príspevok predstavuje čast' grantového projektu Grantovej vedeckej agentúry MŠ SR a SAV VEGA č. č. 1/0359/12 Analýza synchrónnej a diachrónnej hydronymie povodia Hornádu. 
univerzite sa pod vedením D. Slančovej venuje výskumu komunikačných registrov rôznych sociálnych skupín - abuzerov psychotropných látok, hiphoperov, hráčov kariet, športovcov... D. Slančová uvádza, že „č́m diferencovanejšia je societa, ktorá istý jazyk používa, tým diferencovanejší je aj samotný jazyk; čím diferencovanejšie sú komunikačné sféry a typy komunikačných situácií, tým viac sa diferencuje preferenčný spôsob vyjadrovania, spätý s týmito sférami a situáciami” [Slančová 1999: 93]. Jednotlivé society používajú charakteristické lexikálne prostriedky označované termínom register, ktorý je definovaný ako „situačne podmienený spôsob jazykového prejavu, spätý s konkrétnym druhom spoločnej činnosti l'udí" [ibidem: 96]. Register je širší termín ako sociolekty (slangizmy, profesionalizmy, argotizmy) - tak to chápe M. Ološtiak [2011: 271] aj D. Slančová, ktorá vymedzuje dvojaké chápanie registra - sociolingvistické a pragmatické. Sociolingvistické chápanie registra je úzko spojené s rečovými varietami rozličných sociálnych skupín poprepájaných spoločnými záujmami alebo profesiou, pričom podstatou registra nie je len samotná lexika viažuca sa na sociálnu skupinu a jej činnost', ale aj používanie frazeologizmov alebo špeciálnych gramatických konštrukcií [Slančová 1999: 95]. Register nepredstavuje okrajovú čast' jazyka, ale tvorí aktívnu zložku komunikácie $\mathrm{v}$ rámci sociálnych interakcií príslušníkov daných societ. Komplexný komunikačný register človeka je individuálny, zložený z mnohých čiastkových subregistrov, ktoré závisia od počtu a druhu sociálnych skupín, ktorých súčast'ou daný jednotlivec je. D. Slančová hovorí aj o aktívnych a pasívnych komunikačných registroch jednotlivca, ktorých rozsah a stupeň ovládania poukazuje na jazykovú skúsenost' jedinca a môže sa prejavit' napr. pri paródii, scénkach imitujúcich iné sociálne skupiny, žartoch a pod. Zo sociologického hl'adiska tieto komunikačné aktivity predstavujú hranie rol a napodobňovanie statusov iných ako vlastných sociálnych skupín, ktorým zodpovedá príslušný komunikačný register.

Repertoár komunikačného registra society, ako súbor všetkých subregistrov jednotlivých členov skupiny, poukazuje na jedinečnost' tejto skupiny a odlišnost' od ostatných spoločenstiev. Zjednocujúcim činitel'om sociálnych skupín do väčších celkov sú rovnaké alebo vel'mi podobné situačné podmienky, ktoré ponúkajú podmienky na vytváranie vel'mi podobných komunikačných registrov. Na príslušnost' jednotlivca ku skupine potom poukazuje ovládanie registra danej sociálnej skupiny týmto jednotlivcom. Neoddelitel'nou súčast'ou komunikačného registra sú aj vlastné mená. Rozsah onymie ako súboru všetkých vlastných mien registra je determinovaný potrebami presne pomenovat', identifikovat' a diferencovat' objekty sveta, v ktorom sa daná spoločnost' pohybuje.

Pragmatickú rovinu komunikačného registra charakterizuje D. Slančová ako „schopnost' l'udí naznačovat' a menit' svoj postoj ku komunikačným partnerom pomocou jazykových prostriedkov. Tak potom rozoznávame formálny a neformálny register, ktorý sa často jazykovo prejavuje pomocou odlišných oslovovacích foriem, napr. vykanie - tykanie" [Slančová 1999: 95-96]. Problematike oficiálne- 
ho a neoficiálneho komunikačného úzu a ich vplyvom na formu vlastných mien sa v minulosti venoval napr. Władysław Lubaś [1980] alebo Vincent Blanár [1996].

Pragmatická rovina registra sa $\mathrm{v}$ toponymii spája $\mathrm{s}$ výberom topolexém v momente tvorby toponyma, markantnejšie však pragmatickú funkciu uplatňuje človek pri používaní hypokoristických podôb antroponým, ale aj zooným, prezývok a pod. v závislosti od druhu sociálnej skupiny, momentálnej nálady a pod.

Názor D. Slančovej o tom, že repertoár komunikačného registra society je tvorený subregistrami jednotlivých členov skupiny, nás vedie $\mathrm{k}$ zamysleniu sa nad tým, ako tento fakt vplýva na propriá, ktoré sú súčast'ou komunikačného registra. Z komunikačného, funkčného i pragmatického hl'adiska je potrebné odlíšit' antroponymickú zložku registra od toponymickej a tieto dva typy registrov členit' na onymický register jednotlivca ako člena sociálnej skupiny, či skupín a na onymický register skupiny, ktorej jednotlivec je členom.

\section{Komunikačný register $v$ antroponymii}

Antroponymický register jednotlivca (ARJ) predstavuje súbor všetkých antroponým a ich foriem (napr. hypokoristických podôb, prezývok) všetkých členov sociálnych skupín, do ktorých tento jednotlivec patrí a ktoré pozná. ARJ je determinovaný časovou existenciou sociálnych skupín (po zániku skupiny zaniká nominačná funkcia antroponým tejto skupiny), sociálnymi statusmi členov týchto skupín a pragmatickými aspektami vstupujúcich do komunikácie zo strany členov societ [pozri napr. Krško 2000: 77]. ARJ je tak isto ako apelatívny komunikačný register, či slovná zásoba, vnútorne diferencovaný na subregister blízkych osôb, subregister okrajových osôb, prípadne môžeme vyčlenit' subregister osôb, ktoré netvoria s jednotlivcom sociálne skupiny (antroponymá tzv. spoločenského alebo kultúrneho kontextu [k tomu Ološtiak 2007: 188] - mená umelcov, športovcov, politikov...).

Každý človek sa stáva súčast'ou rôznych societ od svojho narodenia až po smrt' - po narodení je súčast'ou rodiny, v ktorej má statusy diet'at'a, súrodenca, vnuka, postupne sa okruh jeho sociálnych skupín rozširuje - stáva sa súčast’ou kolektívu v materskej škole, základnej, strednej, často vysokej škole. Popri týchto societach paralelne existuje $\mathrm{v}$ rôznych záujmových skupinách, neskôr pracovných kolektívoch, získava status manžela, milenca, otca, starého otca. Niektoré sociálne statusy jednotlivec získava (narodí sa do viacpočetnej rodiny s odstupom mnohých rokov od starších súrodencov, narodí sa ako dvojča, prípadne je jedináčikom...), niektoré statusy získa postupne - v školskom kolektíve sa postupne vypracuje na šikovného žiaka ochotného pomôct' spolužiakom, na pracovisku získa vedúcu funkciu, pretože tomu zodpovedá jeho vzdelanie a schopnosti. Všetkým sociálnym statusom zodpovedá dynamický aspekt statusu - sociálna rola, ktorá sa vykonáva, hrá. Rola je súbor určitých povinností, 
obmedzení, predpísaného správania, ale aj súbor privilégiii ${ }^{2}$. Z hl'adiska proprií však k jednotlivým sociálnym statusom patria aj rôzne podoby antroponým tvoriace antroponymický register jednotlivca.

Tým, že jedinec je súčast'ou viacerých societ, jeho antroponymický register predstavuje súčet subregistrov všetkých societ, ktorých je členom.

Analýze ARJ sa doteraz nevenovala pozornost', skôr išlo o výskum prezývok v konkrétnych sociálnych skupinách - skúmali sa prezývky žiakov na základných, stredných a vysokých školách, prezývky v učitel'skom kolektíve, hypokoristické podoby mien $\mathrm{v}$ rodinnom prostredí atd', čiže sa skúmal antroponymický register (sociálnej) skupiny (ARS), ktorý predstavuje súčet všetkých antroponým a ich foriem (napr. hypokoristických podôb, prezývok) členov tejto skupiny. Členovia society ovládajú antroponymický register svojej skupiny - napr. výskumom na ZŠ v Bobrove r. 2004 sme získali 82 prezývok u 50 nositel'ov [Krško 2006: 9] - antroponymický register skupiny v tomto prípade by obsahoval prezývky Sisa, Opička, Mary, Rajo, Simson, Deňa, Zajac, Elvis, Párky, Buchta, Panáčik, Žirafa, Ryšavec, Pavúk, Fúzač atd'. Ale členovia society neovládajú celkový antroponymický register každého člena skupiny - spolužiaci na vysokej škole vedia všetky podoby prezývok spolužiakov v skupine, ale nevedia, ako konkrétnu spolužiačku volajú doma, v jej rodnej dedine, akú prezývku mala na strednej škole, ako ju oslovuje starý otec a pod.

Zložitost' sociálnych väzieb a začlenenie jednotlivca do viacerých sociálnych skupín v súčasnosti výrazne odhal'ujú internetové sociálne siete - každý člen takejto siete má zoznam priatel'ov, sú tam však rôzni l’udia - zo školy, z práce, $\mathrm{z}$ detstva, rodinní príslušníci a podobne. Ak nás niekto kontaktuje a požiada o priatel'stvo, niektoré siete ponúkajú novému členovi možnost' pridat' mu našich (spoločných) priatel'ov - v tomto momente si človek uvedomuje diferenciáciu súboru virtuálnych priatel'ov, resp. sociálnu členitost' svojich sociálnych skupín, ktorých je členom a musí starostlivo vyberat' z kontaktov tie, ktoré má spoločné s novoprihláseným priatel'om. Práve tento sociálny aspekt berú niektoré elektronické médiá do úvahy a na urýchlenie hl'adania kontaktov ponúkajú užívatel'ovi roztriedit' si kontakty do viacerých skupín - práca, záujmy, stredná škola, vysoká škola, miesto pôsobenia atd'.

Sociálne vnímanie toponymického priestoru sa v niektorých ukazovatel'och od antroponymie odlišuje. Ide predovšetkým o emocionálny a pragmatický aspekt v komunikácii - človek neprežíva sociálne väzby medzi (ne)živou prírodou a emocionálna prepojenost' s krajinou vyplýva vlastne zo sociálnej prepojenosti s príslušnou skupinou l'udí (obyvatelia rodnej obce, rodinné väzby, priatel'ské väzby a pod.).

${ }^{2}$ Roly sú vymedzené statusom - status diet’at’a mu „predpisuje” poslúchat' rodičov, pomáhat’ $\mathrm{v}$ domácnosti, nepozerat' večerné televízne programy a pod. Status riaditel'a podniku mu predpisuje správat' sa kultúrne ku klientom, chodit’ vhodne oblečený, byt' diplomatický vo vyjadrovaní... 


\section{Komunikačný register $v$ toponymii}

Tak isto ako pri antroponymických systémoch, môžeme aj v toponymii uvažovat' o toponymickom registri jednotlivca (TRJ) a toponymickom registri (sociálnej) skupiny (TRS).

Pri vytváraní TRJ platia v zásade tie isté pravidlá - ide o priesečník toponymických subregistrov societ ${ }^{3}$, ktorých jednotlivec je členom. Rôznym druhom sociálnych skupín a vzniku sociálnych toponým sme venovali pozornost' v mnohých štúdiách [najmä Krško 1998a; 1998b; 2003b], v ktorých sme rozdelili sociálne skupiny podla veku - detské, mládežnícke; societa rodiny, obce; sociálne skupiny fungujúce na báze záujmov (pol’ovníci, rybári, športovci...) 4 $^{4}$ Sociálne toponymá (alebo $\mathrm{v}$ rámci predchádzajúcich úvah - toponymické registre skupín) vznikajú a fungujú v horizontálnom a vertikálnom smere [pozri Krško 2003b: 64]. V rámci vertikálneho smeru môžeme preto uvažovat' o TRS nielen v rozsahu rodnej obce vymedzenej príslušným chotárom, ale môžeme uvažovat' aj o národnej toponymii zviazanej s etnickou skupinou (v porovnaní s inými toponymickými sústavami). K tomuto názoru nás priviedla samotná definícia sociálnych toponým, ktoré sú definované ako špecifické vlastné mená charakteristické pre určitú, relatívne uzavretú societu, odlišujúce toto spoločenstvo od spoločenstiev susedných. Tento druh proprií sa vyznačuje nízkou komunikačnou potenciou, pretože (z hl'adiska väčších societ) označuje málo dôležité geomorfologické objekty ${ }^{5}$ a časovou a priestorovou ukotvenostou. Časová a priestorová ukotvenost' znamená, že sociálne toponymum existuje len v čase existencie sociálnej skupiny a viaže sa na konkrétny onymický priestor [Krško 2003b: 64].

Na záver možno zhrnút' - propriá sú neoddelitel’nou súčast'ou slovnej zásoby jazyka a tak isto ako apelatívna lexika, aj vlastné mená podliehajú diferenciácii podl'a komunikačných sfér, komunikačných situácií a komunikačných registrov. V rámci individuálneho registra jednotlivca môžeme uvažovat' o antroponymickom a toponymickom registri jednotlivca a sociálne antroponymá a toponymá fungujú $\mathrm{v}$ rámci sociálnych skupín a tvoria antroponymický a toponymický register týchto skupín.

${ }^{3}$ Nedá sa uvažovat' o mechanickom súčte všetkých subregistrov sociálnych skupín, ktorých členom daný jednotlivec je, pretože jednotlivec nemusí ovládat' celý toponymický register skupiny - napr. nie každý človek v obci ovláda všetky toponymá danej obce, hoci patrí do danej society. Ak sa preruší kontakt s rodinou (čiže máme na mysli rodinný toponymický register) - dieta dospeje, ožení sa a odst'ahuje sa, stráca kontinuitu s novým názvami v tomto registri, preto ich nemusí ovládat'.

${ }^{4}$ Počas prípravy podkladov na tento príspevok sme získali zaujímavú štúdiu J. Dumu [2011] o názvoch zátok z prostredia rybárov. Autor štúdie sa odvoláva aj na d'alšie podobné štúdie - tieto materiály vlastne dokumentujú existenciu a fungovanie osobitných a špecifických toponým v societe rybárov, teda autori týchto štúdií analyzujú TRS rybárov.

${ }^{5}$ Označit' objekt, resp. hodnotit' jeho dôležitost' je relatívne, pretože niekedy (v málo členitom teréne) je dôležitá akákol'vek odlišnost' (vyvýšenina, údolie, odlišná vegetácia, u vodných tokov - tvar, koryto a pod.). Naopak, v členitom teréne sú dôležité len vel'mi výrazné javy. Dôležitost' objektu teda rastie v závislosti od detailného „pohl’adu” na krajinu. 


\section{Bibliografia}

Blanár Vincent, 1996, Teória vlastného mena, Bratislava.

Duma Jerzy, 2011, Klomia i inne wielkopolskie nazwy jeziornych toni rybackich zwiazane z określeniami zwierząt wodnych oraz narzędziami do ich połowu, „Prace Językoznawcze” XIII, 87-92.

Krško Jaromír, 1998a, Mikrosociálne toponymá, [in:] 13. Slovenská onomastická konferencia. Zborník referátov z 13. slovenskej onomastickej konferencie konanej v Modre-Piesku 2.-4. októbra 1997, Bratislava, 115-119.

Krško Jaromír, 1998b, Toponymický priestor v komunikácii malých sociálnych skupín, Slovenský národopis, 46, č. 1, 80-101.

Krško Jaromír, 2000, Sociálno-psychologické aspekty pomenovania, [in:] Jaromír Krško, Milán Majtán (eds.), Vlastné mená v jazyku a spoločnosti. Zbornik referátov zo 14. slovenskej onomastickej konferencie, Banská Bystrica 6.-8. júla 2000, Bratislava-Banská Bystrica, 75-84.

Krško Jaromír, 2001, Fungovanie proprií v rôznych komunikačných situáciách, [in:] Jazyková komunikácia v 21. storočí. Zborník zo 4. medzinárodnej vedeckej konferencie o komunikácii, Banská Bystrica, 13.-14. septembra 2000, Banská Bystrica, 241-247.

Krško Jaromír, 2003a, Propriá v mediálnom priestore, [in:] Komunikácia a text. Zborník referátov z konferencie Komunikácia a text, Prešov, 15.-16. novembra 2001, Prešov, 304-311.

Krško Jaromír, 2003b, Sociálny priestor v onymii (Vznik onymických subsystémov - sociálnych toponým), [in:] Metodologia badań onomastycznych, Olsztyn, 61-70.

Krško Jaromír, 2003c, Úloha stredu a okraja societ pri tvorbe vlastných mien, [in:] Okraj a střed v jazyce a literatuře. Sborník z mezinárodni konference, Ústí nad Labem, 82-86.

Krško Jaromír, 2006, Komparácia slovenských a pol’ských žiackych prezývok, [in:] Jaromír Krško (ed.), Sociálny kontext onymie, Banská Bystrica-Prešov, 6-14.

Lubaś Władysław, 1980, Społeczne warianty nazw własnych we współczesnej polszczyźnie, [in:] Spoločenské fungovanie vlastných mien. VII. slovenská onomastická konferencia. (Zemplínska širava 20.-24. septembra 1976.) Zborník materiálov, Bratislava, 25-30.

Ološtiak Martin, 2007, Jazykovoštruktúrny a komunikačno-pragmatický status vlastného mena (adaptácia anglických proprií v slovenčine), Prešov.

Ološtiak Martin, 2011, Aspekty teórie lexikálnej motivácie, Prešov.

Slančová Daniela, 1999, Potrebuje reflexia súčasnej slovenskej jazykovej situácie pojem register?, [in:] Retrospektívne a perspektívne pohlady na jazykovú komunikáciu, I. diel, Materiály z 3. konferencie o komunikácii, Banská Bystrica-Donovaly, 11.-13. septembra 1997, 93-100.

\section{Jaromír Krško}

\section{Communication register and proprium}

\section{(Summary)}

The paper deals with functioning of proper names in various communication situations and social communities. Proprium is an inseparable part of vocabulary and likewise appellative lexis, proper names are also differentiated according to communication spheres, communication situations and communication registers. The paper also emphasizes different application of the antroponymic part of proper names in communication as compared with toponymy.

Słowa kluczowe: rejestr kumunikacyjny, rejestr indywidualny, rejestr społeczny, wspólnota komunikacyjna, proprium.

Key words: communication register, individual register, group register, social community, proprium. 